\title{
Analisis Pengaruh Ukuran Perusahaan, Jenis Industri, Umur Perusahaan, Dan Penerbitan Sukuk Terhadap Tingkat Pengungkapan Islamic Social Reporting (Isr) Pada Perusahaan Yang Terdaftar di Daftar Efek Syariah (Des) Tahun 2010-2012
}

\author{
[Devi Citravury] , [Sri Mulyati]
}

[Icih]

[STIE Sutaatmadja, Subang, Indonesia] Email: [devicitnih2009@gmail.com] b[STIE Sutaatmadja, Subang, Indonesia] Email: [srimulyati82@gmail.com] [STIE Sutaatmadja, Subang, Indonesia] Email: [icih811@yahoo.com]

\begin{tabular}{l} 
INFO ARTIKEL \\
Histori Artikel : \\
Tgl. Masuk : 19 Mei 2019 \\
Tgl. Diterima : 21 Juni 2019 \\
Tersedia Online :11 Juli 2019 \\
\hline
\end{tabular}

Keywords:

Islamic Social Reporting (ISR), size of company, type industry, age and the issuance of sukuk.

\section{ABSTRAK/ABSTRACT}

The research aim of this study is to obtain an empirical evidence about factor that affect Islamic Social Reporting (ISR) in company's annual report. The factors that used in this study such as: industry size, type industry, age of firm and issuance of Sukuk. Measurement of Islamic Social Reporting is based Islamic Social Reporting Index asseen from the company's annual report.

Populations in this study are all companies that listed in Shariah Securities (Daftar Efek Syariah-DES). DES are collection of securities that are not contradict with Islamic principles and have been approved by BAPEPAM and LK. The sampling method in thistudy is purposive sampling. The total number of samples in this study were 63 research samples. The analytical techniques was conducted by multiple regression method and also classical assumption test.

The analysis showed that industry size, type industry, and age of firm significantly positive influence the the level of disclosure of Islamic Social Reporting (ISR) in Indonesia. Meanwhile, issuance of Sukuk had no effect to the level of disclosure of Islamic Social Reporting (ISR) in Indonesia.

\section{PENDAHULUAN}

Seiring dengan perkembangannya keberlangsungan hidup (sustainability) perusahaan tidak lagi hanya ditentukan oleh nilai perusahaan yang dikenal dengan konsep single bottom line, melainkan bergeser ke arah konsep triple bottom line. Konsep single bottom line adalah sebuah konsep yang hanya menekankan pada pencapaian laba perusahaan secara maksimal pada laporan laba rugi. Sedangkan konsep triple bottom line selain menekankan pada pencapaian laba maksimal juga memperlihatkan bentuk tanggung jawab sosial dan tanggung jawab lingkungan. Konsep triple bottom line ini muncul seiring dengan hadirnya isu pengungkapan corporate social responsibility (CSR) yang menjadi banyak perhatian baik negara maju maupun negara berkembang (Elkington, 1994)

Isu CSR ini menjadi sorotan penting dalam beberapa dekade belakangan ini. Sebuah konsep yang dikemukakan oleh Friedman (1982) yaitu keberlanjutan perusahaan tidak ditentukan semata-mata oleh laba perusahaan (profit) tetapi juga 
tergantung pada tanggungjawab tersebut kepada karyawan dan masyarakat sekitar (people) serta lingkungan (planet). Hal ini berdampak perusahaan tidak hanya bertanggung jawab pada pemegang saham (shareholders) dalam bentuk pertanggungjawaban hukum dan ekonomi, melainkan juga kepada para pemangku kepentingan (stakeholders). Salah satu alat perusahaan untuk mengkomunikasikan informasi keuangannya kepada stakeholders adalah laporan keuangan (Ousama dan Fatima, 2006). Komunikasi tersebut menggambarkan akuntabilitas perusahaan kepada para stakeholdemya (Gray et al., 1995).

Di Indonesia konsep CSR sudah mengalami perkembangan yang cukup baik, seiring dengan meningkatkan perhatian masyarakat global terhadap perkembangan perusahaan transnasional dan multi nasional di Indonesia (Utama, 2007). Perkembangan terhadap CSR di Indonesia juga didukung oleh pemerintah dengan ditetapkannya Undang-Undang Nomor 40 Tahun 2007 Pasal 66 ayat 1c tentang Perseroan Terbatas yang salah satu isinya adalah laporan tahunan harus memuat laporan pelaksanaan tanggung jawab sosial dan lingkungan.

Konsep CSR tidak hanya berkembang di ekonomi konvensional, tetapi juga berkembang di ekonomi Islam. Dewasa ini sudah semakin banyak perusahaan-perusahaan yang menerapkan prinsip syariah dalam kegiatan bisnisnya. Salah satu aspek yang mendapat sorotan agar sesuai dengan prinsip-prinsip Islam adalah tanggung jawab sosial perusahaan. Siwar dan Hossain (2009) memaparkan bahwa nilainilai Islam yang dibawa oleh Nabi Muhamad SAW juga dapat digunakan sebagai landasan dari tanggung jawab sosial perusahaan sama seperti konvensional. Islam bukan hanya sebuah agama, melainkan juga sebuah petunjuk kehidupan bagi umat-Nya. Al-Quran berisi berbagai macam petunjuk mengenai hukum, ekonomi, sosial, politik, dan jihad. Mereka juga memaparkan bahwa Islam menempatkan manusia sebagai khalifah Allah SWT.
Oleh karena itu, sebagai khalifah manusia memiliki tanggung jawab untuk memelihara seluruh ciptaan Allah SWT (Siwar dan Hossain, 2009). Konsep CSR dalam Islam lebih ditekankan sebagai bentuk ketakwaan umat manusia kepada Allah SWT dalam dimensi perusahaan. Dalam penelitiannya Siwar dan Hossain (2009), mereka menyimpulkan bahwa nilai-nilai Islam memiliki hubungan yang relevan dan memiliki kontribusi terhadap konsep CSR yang telah berkembang sampai saat ini. Dalam hal ini, Islam memandang perusahaan tidak hanya sebagai caretajer bagi pemegang saham, tetapi juga bagi masyarakat secara keseluruhan dengan tujuan untuk mendapatkan berkah Allah SWT. Paradigma takwa kepada Allah SWT menginspirasi perusahaan untuk selalu melakukan kegiatan bisnis dengan baik serta bertanggung jawab terhadap kehidupan sosial.

Konsep CSR dalam Islam erat kaitannya dengan perusahaanperusahaan yang menjalankan kegiatan bisnisnya sesuai dengan konsep syariah. Perusahaan tersebut diharapkan dapat melakukan tanggung jawab sosial perusahaan yang juga sesuai dengan konsep syariah. Semakin banyaknya perusahaan-perusahaan syariah yang bermunculan mengindikasikan bahwa ekonomi Islam sedang mengalami perkembangan yang cukup pesat. Berikut dibawah ini data perkembangan perusahaan yang masuk Daftar Efek Syariah dalam beberapa tahun terakhir.

\section{Gambar 1 Perusahaan Dalam Daftar Efek Syariah 2008-2012}

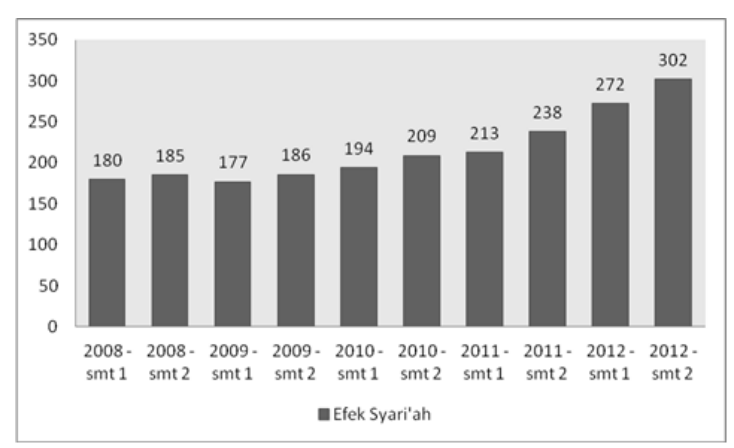

Sumber : Daftar Efek Syariah BEI diolah kembali 
Dapat dilihat pada gambar diatas tentang data perkembangan perusahaan yang masuk dalam Daftar Efek Syariah selama kurun waktu 5 (lima) tahun terakhir, dari tahun ke tahun mengalami peningkatan yang cukup signifikan, dalam perkembangan tersebut tidak dapat dipungkiri hal ini menunjukan bahwa kebutuhan masyarakat terhadap lembaga atau institusi syariah semakin besar dari waktu ke waktu.

Dengan demikian, pasar modal syariah memiliki peranan penting dalam rangka meningkatkan pangsa pasar perusahaan yang berbasis syariah di Indonesia. Pasar modal syariah Indonesia identik dengan Jakarta Islamic Index (JII). Pasar modal ini terdiri dari 30 saham syariah yang tercatat di Bursa Efek Indonesia. Namun, Efek Syariah yang terdapat di pasar modal syariah tidak hanya berjumlah 30 saham syariah. Bapepam dan LK mengeluarkan Daftar Efek Syariah (DES) pada november 2007 yang kemudian menjadikan DES sebagai satu-satunya rujukan tentang Efek Syariah di pasar modal Indonesia.

Perusahaan yang masuk dalam Daftar Efek Syariah ini diharapkan dapat menyajikan suatu dimensi religi ketika melakukan pengungkapan dalam laporan keuangan dalam membantu stakeholders terutama yang beragama Islam dalam mengambil keputusan (Othman dan Thani, 2010). Untuk mengukur sejauh mana perusahaan tersebut menyajikan aspek pertanggungjawaban sosial dari sudut pandang Islam diperlukan sebuah petunjuk. Othman et al. (2009) mengembangkan indeks pengungkapan aspek pertanggungjawaban sosial dalam sudut pandang Islam dalam Islami Social Reporting (ISR). Konsep ini pertama dikemukakan oleh Haniffa (2002) kemudian dikembangkan oleh Othman et al. (2009). Terbatasnya laporan sosial konvensional dalam mengungkapkan aspek-aspek yang sesuai dengan hukum Islam memerlukan kerangka konseptual ISR.
Islami Social Reporting (ISR) adalah standar pelaporan kinerja sosial perusahaan-perusahaan yang berbasis syariah. ISR memiliki dua tujuan utama, yaitu sebagai bentuk akuntabilitas kepada Allah SWT dan masyarakat untuk meningkatkan transparansi kegiatan bisnis dengan cara memberikan informasi yang relevan dan sesuai dengan kebutuhan spiritual para pembuat keputusan Muslim. Indeks ISR berisi kompilasi item-item standar CSR yang ditetapkan oleh AAOIFI (Accounting and Auditing Organization for Islamic Financial Institutions) adalah organisasi internasional Islam non-badan hukum nirlaba yang menyiapkan standar akuntansi, audit, pemerintahan, etika dan standar Syariat Islam lembaga keuangan dan industri, kemudian dikembangkan oleh masing-masing peneliti berikutnya. Secara khusus indeks ini adalah perluasan dari standar pelaporan kinerja sosial yang meliputi harapan masyarakat tidak hanya mengenai peran perusahaan dalam perekonomian, tetapi juga peran perusahaan dalam perspektif spiritual. Selain itu indeks ini juga menekankan pada keadilan sosial terkait mengenai lingkungan, hak minoritas, dan karyawan (Fitria dan Hartati, 2010).

Praktik Islamic Social Reporting telah menjadi salah satu isu yang paling diperdebatkan baik di dunia akademis maupun praktik, hal ini disebabkan banyak sekali kasus mengenai diantaranya melubernya lumpur dan gas panas di Kabupaten Sidoharjo yang disebabkan eksploitasi gas PT Lapindo Brantas, limbah industri PT Wings Surya yang melampaui baku mutu buangan limbah cair yang telah merusak sekitar 18 hektar tanaman padi milik warga, dan tisu Paseo dan kertas produksi Asia Pulp \& Paper $(A P P)$ mendapat cap halal, Selain itu, akhir-akhir ini marak adanya isu kontroversi mengenai pencantuman sertifikasi halal pada obat-obatan. Mengingat memperoleh produk halal bagi setiap konsumen khususnya konsumen muslim adalah hak konstitusional, yang dijamin oleh konstitusi (www.muslimdaily.net). Penerbitan 
sertifikasi halal pada produk merupakan bentuk pengungkapan tanggung jawab sosial perusahaan terhadap stakeholders, khususnya konsumen.

Penelitian ini akan menguji variabel - variabel yang mempengaruhi pengungkapan ISR pada perusahaan perusahaan yang terdaftar dalam Daftar Efek Syariah di Indonesia. Beberapa faktor yang disinyalir dapat mempengaruhi pengungkapan ISR antara lain : ukuran perusahaan, (2) jenis industri, (3) umur perusahaan, (4) penerbitan sukuk. Keempat faktor tersebut sebagai variabel independen yang kemungkinan mempengaruhi pengungkapan ISR. Oleh karena itu perumusan permasalahan dalam penelitian ini adalah : "Apakah faktor - faktor seperti ukuran perusahaan, jenis industri, umur perusahaan dan penerbitan sukuk dapat mempengaruhi pengungkapan ISR pada perusahaan yang terdaftar dalam Daftar Efek Syariah di Indonesia?"

\section{KERANGKA TEORITIS DAN PENGEMBANGAN HIPOTESIS}

\section{Ukuran Perusahaan}

Semakin besar ukuran perusahaan, biasanya informasi yang tersedia untuk investor dalam pengambilan keputusan sehubungan dengan investasi dalam perusahaan tersebut semakin banyak (Siregar dan Utama, 2005). Dengan mengungkapkan kepedulian pada lingkungan melalui pelaporan keuangan, maka perusahaan dalam jangka waktu panjang bisa terhindar dari biaya yang sangat besar akibat dari tuntutan masyarakat. Selain itu perusahaan yang berukuran besar cenderung memiliki public demand terhadap informasi yang lebih tinggi dibanding perusahaan yang berukuran lebih kecil.

Banyaknya pemegang saham menandakan jika perusahaan tersebut memerlukan lebih banyak pengungkapan yang dikarenakan adanya tuntutan dari para pemegang saham dan para analisis pasar modal (Gunawan, 2001). Cowen et al (1987) dalam Sembiring (2003) menyatakan bahwa perusahaan yang lebih besar mungkin akan memiliki pemegang saham yang memperhatikan program sosial yang dibuat perusahaan dalam laporan tahunan, yang merupakan media untuk menyebarkan informasi tentang tanggung jawab sosial keuangan perusahaan. Ayu (2010) menyatakan bahwa ukuran perusahaan tidak hanya memiliki pengaruh yang signifikan terhadap tingkat pengungkapan sukarela, melainkan juga terhadap tingkat pengungkapan wajib.

Adanya dugaan bahwa perusahan yang kecil akan mengungkapkan lebih rendah kualitasnya dibandingkan dengan perusahaan besar, menurut Bubzby (dalam Hasibuan, 2001). Hal ini karena perusahaan ketiadaan sumber daya dan dana yang cukup besar dalam laporan tahunan. Seorang manajemen khawatir apabila dengan adanya pengungkapan yang lebih banyak akan membahayakan posisi perusahaan terhadap kompetitor lain. Ketersediaan sumber daya dan dana membuat perusahaan merasa perlu membiayai penyediaan informasi untuk pertanggungjawaban sosialnya.

Penelitian Cooke (1992), OwusuAnsah (1998), Ho dan Wong (2001), Haniffa dan Cooke (2005) telah membuktikan bahwa ukuran perusahaan yang diukur dengan menggunakan proxy total aset memiliki pengaruh positif signifikan terhadap tingkat pengungkapan wajib ataupun sukarela. Namun, ada pula penelitian yang mengindikasikan bahwa ukuran perusahaan wajib dan sukarela. Penelitian tersebut dihasilkan oleh Akhtarudin (2005) dan Dahawy (2009). Hal ini dikarenakan perusahaan yang lebih besar adalah perusahaan yang memiliki sumber daya lebih banyak dari pada perusahaan yang lebih kecil dan perusahaan yang lebih besar memiliki pembiayaan, fasilitas, dan sumber daya manusia yang lebih banyak untuk dapat melakukan pengungkapan yang lebih sesuai dengan prinsip Islam (Othman et al., 2009).

\section{Jenis Industri}

Beberapa penelitian telah membuktikan secara empiris bahwa tipe 
industri merupakan salah satu faktor yang mempengaruhi tingkat pengungkapan perusahaan kepada masyarakat. Menurut Owusu-ansah (1998), terdapat beberapa alasan mengapa tingkat pengungkapan perusahaan tidak mungkin sama pada jenis industri yang berbeda. Pertama, industri tertentu memiliki aturan sangat ketat karena kontribusi mereka terhadap keseluruhan pendapatan ekspor dan pendapatan nasional negara. Kedua, perusahaan industri tertentu mengalami kesulitan dalam melakukan pelaporan secara memadai karena sifat dari pekerjaan itu sendiri. Misalnya, perusahaan industri pertambangan yang diketahui memiliki perlakuan khusus dalam akuntansi dan pelaporan depresiasi, deplesi, dan eksplorasi sumur minyak. Ketiga, perbedaan pengungkapan juga dapat dihubungkan dengan jenis keragaman produk perusahaan dalam suatu perekonomian. Industri spesifik tertentu akan memanifestasi diri mereka dengan cara berbeda-beda. Misalnya, perusahaan produk konsumen dan perusahaan multiproduk. Perusahaan produk konsumen merupakan perusahaan yang sangat peduli dengan citra publik sehingga perusahaan tersebut akan cenderung mematuhi aturan-aturan yang berlaku. Selain itu, perusahaan multiproduk sudah pasti memiliki informasi yang lebih banyak yang harus diungkapkan ke publik.

Dalam berbagai penelitian, para peneliti mengelompokkan perusahaanperusahaan ke dalam jenis industri tertentu. Pengelompokkan jenis industri dilakukan sesuai dengan tujuan masingmasing penelitian. Ho dan Wong (2001) mengelompokkan menjadi konglomerasi, perbankan dan keuangan, manufaktur, dan lain-lain, Akhtaruddin (2005) mengelompokkan menjadi perusahaan tradisional dan modern, Haniffa dan Cooke (2005) mengelompokkan menjadi industri konsumen, konstruksi atau properti, perdagangan atau jasa, perkebunan, dan industrial, Aljifi (2008) mengelompokkan menjadi sektor perbankan, asuransi, industrial, dan jasa, serta Zourarakis (n.d) mengelompokkan menjadi perusahaan keuangan dan non-keuangan. Penelitianpenelitian terdahulu tersebut menunjukkan hasil yang beragam.

Dalam penelitian ini, tipe industri dikelompokkan menjadi perusahaan yang masuk ke dalam industri manufaktur dan non-manufaktur. Menurut Suwaidan (1997) dalam Omar dan Simon (2011), perusahaan manufaktur menghasilkan polusi yang lebih banyak daripada perusahaan non-manufaktur sehingga informasi tambahan harus diungkapkan dalam laporan tahunan perusahaan manufaktur.

\section{Umur Perusahaan}

Salah satu faktor yang mungkin mempengaruhi tingkat pengungkapan wajib dan sukarela adalah umur perusahaan. Dalam penelitian ini, umur perusahaan dihitung sejak perusahaan terdaftar di Bursa Efek.

Perusahaan dengan umur yang lebih tua kemungkinan besar akan mengungkapkan informasi yang lebih banyak dalam laporan tahunannya dibandingkan dengan perusahaan dengan umur yang lebih muda. Menurut Akhtaruddin (2005), perusahaan dengan umur yang lebih tua akan cenderung mengungkapkan informasi yang lebih banyak dalam laporan tahunannya dengan tujuan untuk meningkatkan reputasi dan citra perusahaan dipasar. Owusu-Ansah (1998) menjelaskan bahwa terdapat tiga alasan mengapa perusahaan dengan umur yang lebih tua akan mengungkapkan informasi yang lebih banyak dibandingkan dengan perusahaan dengan umur yang lebih muda. Pertama, perusahaan dengan umur yang lebih muda akan mengalami kerugian kompetitif apabila ia mengungkapkan mengenai pengeluaran riset, pengeluaran modal, dan pengembangan produk. Kerugian kompetitif akan muncul ketika informasi yang diungkapkan oleh perusahaan yang baru terbentuk itu digunakan oleh kompetitor lain. Di sisi lain, perusahaan dengan umur yang lebih tua justru termotivasi untuk mengungkapkan informasi-informasi itu karena penyajian tersebut tidak akan membahayakan posisi 
kompetitif mereka. Kedua, biaya dan kemudahan dalam mengumpulkan, mengolah, dan menyebarkan informasi yang diperlukan juga dapat dianggap sebagai kendala. Biaya-biaya tersebut merupakan biaya yang sangat besar bagi perusahaan dengan umur yang lebih muda. Ketiga, perusahaan dengan umur yang lebih muda tidak memiliki track record yang dapat diandalkan dalam melakukan pengungkapan publik. beberapa perusahaan dibentuk melalui proses akuisisi atau merger, akan tetapi ada juga perusahaan yang dibentuk dari awal. Perusahaan yang dibentuk dari awal sudah pasti tidak memiliki historis kegiatan operasi sebelumnya sehingga perusahaan yang baru terbentuk cenderung kurang memiliki insentif untuk pengungkapan yang lebih luas.

\section{Penerbitan Sukuk}

Penelitian terdahulu mengenai pengaruh penerbitan sekuritas terhadap tingkat pengungkapan perusahaan pernah dilakukan oleh Marwata (2001), Neograheni (2005), dan Hossain et al. (2006). Ketiga hasil penelitian tersebut membuktikan bahwa penerbitan sekuritas mempunyai pengaruh signifikan tehadap tingkat pengungkapan sukarela. Jenis sekuritas yang digunakan dalam penelitian ini adalah sukuk. Berdasarkan Peraturan BAPEPAM-LK Nomor IX.A.13 tentang Penerbitan Efek Syariah, sukuk adalah efek syariah berupa sertifikat atau bukti kepemilikan yang bernilai sama dan mewakili bagian penyertaan yang tidak terpisahkan atau tidak terbagi atas kepemilikan asset berwujud tertentu, nilai manfaat dan jasa atas asset proyek tertentu atau aktivitas investasi tertentu.

Penelitian mengenai pengaruh penerbitan sukuk terhadap tingkat pengungkapan ISR masih sangat terbatas. Variabel penerbitan sukuk ini merupakan satu-satunya variabel spesipik syariah yang memungkinkan dijadikan sebagai variabel bebas untuk melihat pengaruhnya terhadap ISR dalam konteks Indonesia. Dalam penelitian ini, variabel surat berharga syariah mengadopsi Hossain et al. (2006) yang mengidentifikasi sukuk dilihat dari keberadaannya pada laporan perusahaan di tahun penelitian. Menurut Hossain et al. (2006) informasi yang luas seharusnya diungkapkan bukan hanya saat sekuritas hendak diterbitkan, melainkan juga selama sekuritas tersebut masih menjadi salah satu sumber pendanaan bagi perusahaan. Sepanjang sekuritas tersebut masih menjadi salah satu sumber pendanaan bagi perusahaan, tambahan informasi dibutuhkan untuk menghilangkan keraguan pemegang sekuritas tersebut terhadap terpenuhinya hak-hak mereka (Schipper, 1981). Selain itu, tambahan informasi juga dibutuhkan sebagai salah satu bentuk monitoring pemegang sekuritas atas penggunaan dana. Seorang investor Muslim pasti ingin mengetahui apakah dana yang mereka investasikan benar-benar digunakan untuk kegiatan yang tidak bertentangan syariah islam. Secara spesifik, perusahaan yang terdapat surat berharga syariah dalam laporan tahunannya diperkirakan akan melakukan pengungkapan tanggung jawab sosial secara syariah lebih luas. Hal ini sesuai dengan teori stakeholders. Teori ini menyatakan bahwa perusahaan bukanlah entitas yang hanya beroperasi untuk kepentingan sendiri, namun juga harus memberi manfaat bagi para stakeholdersnya. Sehingga setiap aktivitas perusahaan adalah untuk mencari dukungan stakeholders (Gray, Kouhy dan Adams, 1994 dalam Chariri, 2008, hal. 159).

\section{Pengembangan Hipotesis}

\section{Ukuran Perusahaan dan Islamic Social Reporting}

Ukuran perusahaan dapat diukur dengan menggunakan beberapa cara. Menurut Hossain et al (2006), ukuran perusahaan dapat diukur dengan menggunakan jumlah karyawan, nilai total aset, dan volume penjualan. Namun, ketiga proxy tersebut sangat berkorelasi tinggi antara satu dengan yang lain. Sedangkan, Cooke (1992) memaparkan bahwa ukuran perusahaan dapat diukur dengan modal saham, turnover, jumlah pemegang saham, total aset, aset lancar, 
aset tetap, shareholder's fund dan bank borrowing.

Penelitian terkait ukuran perusahaan dan ISR pernah dilakukan oleh Othman et al. (2009) dan Rhimenda (2013). Hasil penelitian Othman et al. (2009) dan Rhimenda (2013) selaras dengan kebanyakan penelitian-penelitian sebelumnya, yakni ukuran perusahaan secara positif signifikan mempengaruhi tingkat pengungkapan ISR. Berdasarkan penelitian sebelumnya oleh Othman et al (2009), penelitian ini menduga bahwa perusahaan yang lebih besar akan cenderung melakukan pengungkapan ISR secara lebih luas. Dengan demikian penelitian ini merumuskan ke dalam hipotesis:

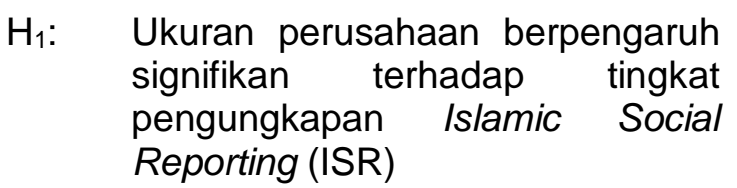

\section{Jenis Industri dan Islamic Social Reporting}

Jenis industri dikelompokkan menjadi perusahaan yang masuk ke dalam industri manufaktur dan nonmanufaktur. Menurut Suwaidan (1997) dalam Omar dan Simon (2011), perusahaan manufaktur menghasilkan polusi yang lebih banyak daripada perusahaan non-manufaktur sehingga informasi tambahan harus diungkapkan dalam laporan tahunan perusahaan manufaktur. Penelitian yang berkaitan dengan ISR telah dilakukan oleh Putri (2014) mengungkapkan bahwa Jenis industri memiliki pengaruh terhadap tingkat ISR sedangkan Othman et al. (2009) berpendapat bahwa tidak ada pengaruh signifikan antara tipe industri terhadap tingkat Islamic Social Reporting (ISR) dengan perusahaan manufaktur memberikan pengungkapan yang lebih luas dibandingkan dengan perusahaan non-manufaktur. Berdasarkan analisis di atas, penelitian ini memprediksi bahwa terdapat pengaruh signifikan antara jenis industri terhadap tingkat pengungkapan Islamic Social Reporting (ISR) dengan perusahaan manufaktur memberikan pengungkapan yang lebih luas dibandingkan dengan perusahaan nonmanufaktur. Hal ini sesuai dengan teori legitimasi. Teori ini secara eksplisit mengakui bahwa bisnis dibatasi kontrak sosial yang menyebutkan bahwa perusahaan sepakat untuk menunjukkan berbagai aktivitas sosial perusahaan agar perusahaan memperoleh penerimaan masyarakat akan tujuan perusahaan yang pada akhirnya menjamin kelangsungan hidup perusahaan (Brown and Deegan, 1998; Guthrine and Parker, 1989; Deegan, 2002). Dengan demikian penelitian ini merumuskan ke dalam hipotesis:

$\begin{array}{llr}\mathrm{H}_{2} \text { : } & \text { Jenis Indusrti berpengaruh } \\ & \text { signifikan terhadap tingkat } \\ & \text { pengungkapan Islamic } & \text { social } \\ & \text { Reporting (ISR) } & \end{array}$

\section{Umur Perusahaan dan Islamic Social Reporting}

Salah satu faktor yang mungkin mempengaruhi tingkat pengungkapan wajib dan sukarela adalah umur perusahaan. Dalam penelitian ini, umur perusahaan dihitung sejak perusahaan terdaftar di Bursa Efek. Perusahaan dengan umur yang lebih muda diprediksi akan melakukan penyebaran informasi yang lebih banyak dibandingkan perusahaan dengan umur yang lebih tua dengan tujuan untuk mengurangi ketidakpastian risiko operasi serta untuk meningkatkan kepercayaan diri investor terhadap posisi mereka (Haniffa dan Cooke, 2002)

Beberapa hasil penelitian sebelumnya membuktikan bahwa terdapat hubungan positif antara umur perusahaan dengan tingkat pengungkapan wajib maupun sukarela (Owusu-Ansah (1998); Liu dan Anbumozhi (2008); Hossain dan Hammami (2009); dan Omar dan Simon (2011). Sebaliknya hasil penelitian oleh Marwata (2001), Sembiring (2003), dan Akhtaruddim (2005) menunjukkan bahwa umur perusahaan bukan merupakan proxy yang signifikan mempengaruhi tingkat pengungkapan perusahaan. Penelitian ini memperkirakan bahwa perusahaan dengan umur yang lebih muda akan 
melakukan pengungkapan tanggung jawab sosial secara syariah yang lebih luas.

$\mathrm{H}_{3}$ : Umur Perusahaan berpengaruh signifikan terhadap tingkat pengungkapan Islamic Social Reporting (ISR)

\section{Penerbitan Sukuk dan Islamic Social Reporting}

Penelitian mengenai pengaruh penerbitan sukuk terhadap tingkat pengungkapan ISR masih sangat terbatas. Variabel penerbitan sukuk ini merupakan satu-satunya variabel spesipik syariah yang memungkinkan dijadikan sebagai variabel bebas untuk melihat pengaruhnya terhadap ISR dalam konteks Indonesia. Dalam penelitian ini, variabel surat berharga syariah mengadopsi Hossain et al. (2006) yang mengidentifikasi sukuk dilihat dari keberadaannya pada laporan perusahaan di tahun penelitian. Menurut Hossain et al. (2006) informasi yang luas seharusnya diungkapkan bukan hanya saat sekuritas hendak diterbitkan, melainkan juga selama sekuritas tersebut masih menjadi salah satu sumber pendanaan bagi perusahaan. Sepanjang sekuritas tersebut masih menjadi salah satu sumber pendanaan bagi perusahaan, tambahan informasi dibutuhkan untuk menghilangkan keraguan pemegang sekuritas tersebut terhadap terpenuhinya hak-hak mereka (Schipper, 1981). Selain itu, tambahan informasi juga dibutuhkan sebagai salah satu bentuk monitoring pemegang sekuritas atas penggunaan dana. Seorang investor Muslim pasti ingin mengetahui apakah dana yang mereka investasikan benar-benar digunakan untuk kegiatan yang tidak bertentangan syariah islam. Secara spesifik, perusahaan yang terdapat surat berharga syariah dalam laporan tahunannya diperkirakan akan melakukan pengungkapan tanggung jawab sosial secara syariah lebih luas. Hal ini sesuai dengan teori stakeholders. Teori ini menyatakan bahwa perusahaan bukanlah entitas yang hanya beroperasi untuk kepentingan sendiri, namun juga harus memberi manfaat bagi para stakeholdersnya. Sehingga setiap aktivitas perusahaan adalah untuk mencari dukungan stakeholders (Gray, Kouhy dan Adams, 1994 dalam Chariri, 2008, hal. 159).

$\begin{array}{lcr}\text { Penelitian } & \begin{array}{c}\text { mengenai } \\ \text { sekuritas }\end{array} & \begin{array}{r}\text { pengaruh } \\ \text { terhadap }\end{array} \\ \text { penerbitan } & \text { pengungkapan perusahaan } & \text { pernah } \\ \text { dilakukan oleh Marwata } & (2001) \text {, } \\ \text { Noegraheni (2005), dan Hossain et al. }\end{array}$
(2006). Ketiga hasil penelitian tersebut membuktikan bahwa penerbitan sekuritas mempunyai pengaruh signifikan terhadap tingkat pengungkapan sukarela. Jenis sekuritas yang digunakan dalam penelitian ini adalah sukuk. Berdasarkan peraturan BAPEPAM-LK Nomor IX.A.13 tentang Penerbitan Efek Syariah, sukuk adalah efek syariah berupa sertifikat atau bukti kepemilikan yang bernilai sama dan mewakili bagian penyertaan yang tidak terpisahkan atau tidak terbagi atas kepemilikan aset berwujud tertentu, nilai manfaat dan jasa atas aset proyek tertentu atau aktivitas investasi tertentu.

Dengan demikian, penelitian ini menduga bahwa terdapat perbedaan pengungkapan tanggung jawab sosial secara syariah di antara perusahaan yang menerbitkan surat berharga dan perusahaan yang tidak menerbitkan surat berharga. Dengan demikian penelitian ini merumuskan ke dalam hipotesis:

$\begin{array}{rlr}\mathrm{H}_{4}: & \text { Penerbitan Sukuk berpengaruh } \\ & \text { signifikan terhadap } r & \text { tingkat } \\ & \text { pengungkapan Islamic } & \text { Social } \\ & \text { Reporting (ISR) } & \end{array}$

\section{METODOLOGI PENELITIAN}

\section{Jenis Data, Populasi dan Sampel}

Jenis data yang digunakan dalam penelitian ini adalah data dokumenter, yaitu laporan tahunan (annual report) selama tahun 2010-2012 dari perusahaan - perusahaan yang terdapat pada Daftar Efek Syariah. Sumber data yang digunakan dalam penelitian ini adalah data sekunder, yaitu berupa laporan tahunan tahun 2010-2012. Daftar Efek Syariah diperoleh dari situs Bapepam-LK (www.bapepam.go.id) berupa annual report pada situs BEI (www.idx.go.id) yang digunakan untuk mengisi indeks Islamic 
Social Reporting. Pemilihan sampel dilakukan secara Purposive sampling merupakan proses pengambilan sampel yang membatasi jumlah sampel sesuai dengan kriteria-kriteria yang ditetapkan oleh peneliti. Purposive sampling merupakan salah satu teknik yang paling sering digunakan dalam penelitian kuantitatif (Sekaran, 2010).

\section{Definisi Operasional dan Pengukuran Variabe}

Tabel 1. Rangkuman Variabel Bebas, Proxy, dan Dugaan Tanda

\begin{tabular}{|c|c|c|c|c|}
\hline $\begin{array}{c}\text { Simbol } \\
\text { Variabel }\end{array}$ & Variabel & Proxy & $\begin{array}{c}\text { Dugaan } \\
\text { Tanda }\end{array}$ & Penelitian Terdahulu \\
\hline SIZE & $\begin{array}{c}\text { Ukuran } \\
\text { Perusahaan }\end{array}$ & $\begin{array}{c}\text { Natural logaritma dari total } \\
\text { aset }\end{array}$ & + & $\begin{array}{c}\text { Haniffah \& Cooke } \\
\text { (2005), Hossain (2009), } \\
\text { dan Othman et al. } \\
(2009) \text { Rhimeda (2013) }\end{array}$ \\
\hline DINDS & $\begin{array}{c}\text { Jenis } \\
\text { Industri }\end{array}$ & $\begin{array}{c}\text { Industri manufaktur dan } \\
\text { industri non-manufaktur. }\end{array}$ & + & $\begin{array}{c}\text { Hossain et al. (2006), } \\
\text { Othman et al. (2009), } \\
\text { Rhimenda (2013), dan } \\
\text { Putri (2014) }\end{array}$ \\
\hline SUKUK & $\begin{array}{c}\text { Umur } \\
\text { Perusahaan }\end{array}$ & $\begin{array}{c}\text { Selisih antara tahun penelitian } \\
\text { dengan tahun pencatatan } \\
\text { atau tahun IPO (first issue) di } \\
\text { BEl }\end{array}$ & + & $\begin{array}{c}\text { Liu \& Anbumozhi (2008) } \\
\text { dan Hossain \& } \\
\text { Hammami (2009), } \\
\text { Rhimenda (2013) }\end{array}$ \\
\hline Sukuk & $\begin{array}{c}\text { Perusahaan yang } \\
\text { menerbitkan sukuk dengan } \\
\text { perusahaan yang tidak } \\
\text { menerbitkan sukuk }\end{array}$ & + & Raditya (2012) \\
\hline
\end{tabular}

Sumber : Penelitian terdahulu

Variabel terikat dalam penelitian ini adalah nilai dari indeks ISR yang diperoleh dari masing-masing perusahaan setiap tahun. Nilai indeks tersebut diperoleh dengan menggunakan metode content analysis pada laporan tahunan, laporan berkelanjutan, dan atau laporan PKBL. Skoring indeks ISR dalam penelitian ini menggunakan metode content analysis tanpa pembobotan. Indeks ISR dalam penelitian ini terdiri dari 46 item pengungkapan yang tersusun dalam enam tema sesuai penelitian Haniffa (2002) dan penelitian Othaman et.al., (2009). Berikut rumus untuk menghitung besarnya disclosure level setelah scoring pada indeks ISR selesai dilakukan.

$$
\text { Disclosure Level }=\frac{\text { Jumlah skor Disclosure yang dipenuhi }}{\text { Jumlah skor maksimum }} \times 100 \%
$$

\section{Metode Analisis}

Penelitian ini menggunakan software computer SPSS sebagai perangkat pengolahan data. Oleh karena penelitian ini menggunakan analisis regresi linier berganda maka perlu dilakukan uji asumsi klasik. Tujuannya untuk memastikan bahwa data penelitian valid, tidak bias, konsisten, dan penaksiran koefisien regresinya bersifat efisien (Ghozali, 2013). Pengujian asumsi klasik meliputi uji Normalitas, uji multikolinearitas, uji heterokedastisitas dan uji autokorelasi. Model regresi linier berganda dengan persamaan sebagai berikut: 


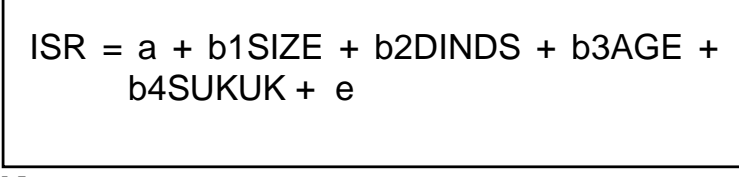

\section{Keterangan:}

ISR : Skor Indeks Pengungkapan Islamic Social Reporting

A : Regresi yang diterima

bi : Parameter yang diestimasi

SIZE : Ukuran Perusahaan, Total Aset (Ln) DINDS : Jenis industri, kategori 8 tipe industri

AGE : Umur Perusahaan

SUKUK : Penerbitan Sukuk Perusahaan

e : Error term

I : $1, \ldots, 4 \ldots(4.1)$

Pengujian pengaruh antara variabelvariabel independen dengan tingkat ISR maka dilakukan pengujian-pengujian hipotesis penelitian menggunakan uji Koefisien Determinasi (Adjusted R2). Uji t digunakan untuk mengetahui kemampuan masing-masing variabel independen secara individu (partial) dalam menjelaskan perilaku variabel dependen dengan tingkat signifikansi $0,05(\mathrm{a}=5 \%)$. Selain itu untuk menguji kesesuaian model penelitian menurut Ghozali (2005) menggunakan uji statistik $F$ dengan menggunakan tingkat signifikansi 0,05 $(a=5 \%)$.

\section{HASIL DAN PEMBAHASAN}

\section{Deskriptif sampel dan Variabel}

Data yang digunakan dalam penelitian ini adalah laporan tahunan dari perusahaan yang terdaftar di Daftar Efek Syariah dan listing di Bursa Efek Indonesia (BEI). Perusahaan-perusahaan yang masuk Daftar Efek Syariah (DES) adalah perusahaan yang tidak bertentangan dengan Prinsip-prinsip Syariah di Pasar Modal selama periode 2010-2012. di bawah ini merupakan rangkuman hasil proses pengambilan sampel yang telah dilakukan.
Tabel 2 Rangkuman Hasil Proses Pengambilan Sampel

\begin{tabular}{|c|l|c|}
\hline No. & \multicolumn{1}{|c|}{ Kriteria } & $\begin{array}{c}\text { Jumlah } \\
\text { Perusahaan }\end{array}$ \\
\hline 1. & $\begin{array}{l}\text { Perusahaan yang } \\
\text { bertahan dalam } \\
\text { Daftar Efek } \\
\text { Syariah sebanyak } \\
\text { delapan periode } \\
\text { dan tercatat } \\
\text { (listed) di BEl } \\
\text { selama kurun } \\
\text { waktu 2010-2012 }\end{array}$ & 85 \\
\hline 2. & $\begin{array}{l}\text { Eliminasi } \\
\text { perusahaan yang } \\
\text { menggunakan } \\
\text { mata uang selain } \\
\text { Rupiah. }\end{array}$ & $(6)$ \\
\hline 3. & $\begin{array}{l}\text { Eliminasi } \\
\text { keterbatasan data }\end{array}$ & $(16)$ \\
\hline \multicolumn{2}{|c|}{ Total Perusahaan } \\
\hline
\end{tabular}

Sumber: Website Bursa Efek Indonesia www.idx.co.id

\section{Islamic Social Reporting}

Tingkat pengungkapan tanggung jawab sosial secara syariah setiap perusahaan berbeda-beda. Ada perusahaan yang melakukan pengungkapan tanggung jawab sosial secara syariah dengan baik, namun ada pula perusahaan yang melakukan pengungkapan tanggung jawab sosial secara syariah dengan sangat minim meskipun perusahaan tersebut telah dikategorikan sebagai perusahaan syariah oleh badan otoritas pasar modal dan lembaga keuangan. Di bawah ini daftar perusahaan dengan skor indeks ISR tiga tertinggi dan tiga terendah. 
Tabel 3 Daftar Perusahaan dengan Skor Indeks ISR Tiga Tertinggi

\begin{tabular}{|c|c|c|c|c|c|c|}
\hline \multirow{3}{*}{ No } & \multicolumn{6}{|c|}{ Skor Indeks ISR Tertinggi } \\
\hline & \multicolumn{2}{|c|}{2010} & \multicolumn{2}{|c|}{2011} & \multicolumn{2}{|c|}{2012} \\
\hline & Kode & Skor & Kode & Skor & Kode & Skor \\
\hline 1 & TINS & 36 & ANTMTINS & 36 & TINS & 36 \\
\hline 2 & $\begin{array}{l}\text { ELSA } \\
\text { SMGR }\end{array}$ & 34 & SMGR & 35 & ANTM & 34 \\
\hline 3 & $\begin{array}{c}\text { AALI } \\
\text { ANTM }\end{array}$ & 33 & $\begin{array}{c}\text { AALI } \\
\text { ANTMELSA }\end{array}$ & 34 & $\begin{array}{l}\text { ELSA } \\
\text { INTP } \\
\text { UNTR }\end{array}$ & 33 \\
\hline
\end{tabular}

Sumber : Hasil Olah Penulis

Berdasarkan Tabel 3 di atas, dapat dilihat bahwa skor indeks ISR tertinggi tahun 2010 diduduki oleh PT. Timah (Persero) Tbk (TINS) dengan skor 36. Sedangkan, skor indeks ISR tertinggi tahun 2011 dimiliki oleh PT Aneka Tambang (Persero) Tbk (ANTM) dan PT. Timah (Persero) Tbk (TINS) dengan skor 36, dan skor indeks ISR tahun 2012 diduduki oleh PT. Timah (Persero) Tbk (TINS) dengan skor 36. Skor indeks ISR tiga tertinggi didominasi oleh perusahaan BUMN yang bergerak di industri manufaktur bidang semen (SMGR), exsportir dan produsen timah (TINS), dan pertambangan (ANTM). Selain itu, perusahaan non-BUMN yang juga menduduki posisi skor indeks ISR tiga tertinggi adalah perusahaan yang bergerak dalam bidang distributor alat berat (UNTR), Jasa hulu migas (ELSA), dan Perkebunan (AALI) Perusahaan BUMN sangat logis jika melakukan pengungkapan tanggung jawab sosial syariah lebih luas karena lebih dari setengah kepemilikan BUMN berasal dari dana pemerintah atau APBN. Dengan kata lain, sebagian besar kepemilikan BUMN merupakan dana masyarakat yang mereka setorkan ke pemerintah melalui sistem pajak. Oleh karena itu, BUMN sudah seharusnya melakukan pengungkapan laporan tanggung jawab sosial secara syariah yang lebih baik dan lebih luas kepada seluruh para pemangku kepentingannya termasuk masyarakat.

Tabel 4 Daftar Perusahaan dengan Skor Indeks ISR Tiga Terendah

\begin{tabular}{|c|c|c|c|c|c|c|}
\hline \multirow{2}{*}{ No } & \multicolumn{6}{|c|}{ Skor Indeks ISR Terendah } \\
\cline { 2 - 7 } & \multicolumn{2}{|c|}{2010} & \multicolumn{2}{c|}{2011} & \multicolumn{2}{c|}{2012} \\
\cline { 2 - 7 } & Kode & Skor & Kode & Skor & Kode & Skor \\
\hline 1 & AIMS & 8 & AIMS & 10 & AIMS & 11 \\
\hline 2 & RDTX & 9 & $\begin{array}{c}\text { LPIN } \\
\text { PSKT }\end{array}$ & 11 & TRIL & 14 \\
\hline 3 & PSKT & 10 & DNET & 12 & PSKT & 15 \\
\hline
\end{tabular}

Sumber : Hasil Olah Penulis 
Berdasarkan Tabel 4 di atas, dapat dilihat bahwa skor indeks ISR terendah PT Akbar Indomakmur Stimec Tbk (AIMS) menempati posisi skor indeks ISR terendah selama tiga tahun berturut-turut, yakni dengan skor 8 pada tahun 2010, 10 skor pada tahun 2011 dan 11 skor pada tahun 2012. Secara tidak langsung, PT. Akbar Indomakmur Stimec Tbk (AIMS) hanya melakukan pengungkapan pokokpokok tanggung jawab sosial syariah sebesar 17\%-21\% dalam laporan tahunannya.

$$
\text { Apabila diperhatikan secara }
$$
seksama, daftar perusahaan yang menempati posisi tertinggi dan terendah relatif sama, meskipun skor indeks ISR masing-masing perusahaan cenderung meningkat dari tahun 2010, 2011, dan 2012. Hal ini menunjukkan bahwa perusahaan cukup konsisten dalam melakukan pengungkapan tanggung jawab sosial secara syariah. Perusahaan dengan skor indeks ISR tinggi akan konsisten untuk melakukan pengungkapan tanggung jawab sosial secara syariah dengan baik. Sedangkan, perusahaan dengan skor indeks ISR rendah juga akan konsisten untuk melakukan pengungkapan tanggung jawab sosial secara syariah dengan sangat minim. Namun, skor indeks ISR yang rendah tidak dapat mutlak disalah artikan bahwa perusahaan tersebut tidak melakukan pengungkapan tanggung jawab sosial secara syariah dengan baik karena terdapat dua kemungkinan, yakni perusahaan tersebut melakukan tanggung jawab sosial sacara syariah akan tetapi tidak diungkapkan dalam laporanlaporannya atau perusahaan tersebut memang tidak melakukan tanggung jawab sosial secara syariah.

Dalam rangka mempertajam analisis, bagian selanjutnya merupakan pembahasan mengenai pokok-pokok pengungkapan setiap tema di dalam pengungkapan ada 6 tema yang berisi 47 pokok pengungkapan. Berikut adalah penjelasan hasil content analysis untuk setiap tema indeks ISR:

\section{Tema Pembiayaan dan Investasi}

Tema pembiayaan dan investasi terdiri dari lima pokok pengungkapan. Pokok pengungkapan kegiatan yang mengandung riba merupakan pokok pengungkapan yang paling banyak dilakukan oleh perusahaan. Pada tahun 2010, 2011 dan 2012 terdapat 61 perusahaan yang konsisten mengungkapkan kegiatan yang mengandung riba dalam laporannya. Pengungkapan tersebut mencakup jumlah utang yang mengandung bunga, jumlah beban bunga, tujuan penggunaan utang yang mengandung bunga, serta pendapatan bunga. Pengungkapan mengenai apakah perusahaan melakukan kegiatan yang mengandung gharar atau tidak mengalami peningkatan dari 39 perusahaan di tahun 2010, 40 perusahaan di tahu n 2011 dan menjadi 44 perusahaan di tahun 2012. Hal ini menunjukkan bahwa perusahaan syariah di Indonesia sudah mulai baik dalam mengungkapkan apakah mereka terlibat dalam kegiatan gharar atau tidak. Hal ini memberikan dampak positif bagi para investor Muslim dalam mengambil keputusan investasi.

Sebagai perusahaan yang sahamnya dikategorikan sebagai saham syariah oleh BAPEPAM dan LK, sudah selazimnya perusahaan tersebut melakukan pembayaran zakat serta mengungkapkannya. Namun, dalam penelitian ini hanya 5 perusahaan di tahun 2010 dan 2011, 4 perusahaan di tahun 2012 yang mengungkapkan perihal terkait kegiatan zakat yang telah mereka lakukan. Tidak diungkapkannya perihal zakat dalam laporan perusahaan mengandung dua kemungkinan, yakni perusahaan telah membayar zakat akan tetapi tidak mengungkapkannya di laporan perusahaan atau perusahaan memang tidak membayar zakat sama sekali sehingga perusahaan tidak melakukan pengungkapan dalam laporannya.

Pokok pengungkapan selanjutnya adalah kebijakan atas keterlambatan pembayaran piutang dan penghapusan piutang tak tertagih. Semua perusahaan mengungkapkan, Salah satu faktor utama yang diduga menyebabkan perusahaan tetap konsisten adalah dengan 
diberlakukannya PSAK 50 (revisi 2006) pada 1 januari 2010 (sesuai dengan surat pengumuman DSAK IAI No. 1705/DSAK/IAI/XII/2008). Dalam PSAK 50 disebutkan bahwa perusahaan harus mengungkapkan mengenai risiko-risiko yang melekat pada kegiatan usaha perusahaan, salah satunya adalah risiko kredit. Dampak dari hal tersebut membuat sebagian besar perusahaan mengungkapkan kebijakan atas pembayaran piutang dan penghapusan piutang tak tertagih secara lebih komprehensif dalam laporannya.

Pokok pengungkapan yang terakhir dalam tema ini terkait dengan ada atau tidaknya pernyataan nilai tambah dalam laporan perusahaan. Jumlah perusahaan yang mengungkapkan hal ini relatif konsisten dalam kurun waktu 2010-2012 karena pernyataan nilai tambah biasanya diungkapkan pada bagian visi, misi, nilainilai perusahaan, laporan Dewan Komisaris, atau laporan Dewan Direksi yang isinya cenderung hampir sama setiap tahun.

Secara keseluruhan, jumlah perusahaan yang mengungkapkan masing-masing pokok pengungkapan pembiayaan dan investasi mengalami peningkatan. Dengan demikian, dapat disimpulkan bahwa semakin ke sini perusahaan syariah semakin meningkatkan kualitas pengungkapan pembiayaan dan investasinya agar lebih sesuai dengan prinsip Islam.

\section{Tema Produk dan Jasa}

Dalam tema produk dan jasa terdapat empat pokok pengungkapan. Pertama, pokok pengungkapan terkait dengan produk atau kegiatan operasi ramah lingkungan. Jumlah perusahaan yang mengungkapkan hal ini mengalami peningkatan sebanyak 5 perusahaan selama tahun 2010-2012. Peningkatan ini berhubungan erat dengan semakin merebaknya isu pemanasan global dalam beberapa tahun belakangan. Isu pemanasan global memicu perusahaanperusahaan di seluruh dunia untuk dapat menghasilkan produk dan/atau melakukan kegiatan operasi yang ramah lingkungan.
Kedua, pokok pengungkapan yang berhubungan dengan kehalalan produk. Pada tahun 2010, perusahaan yang melakukan pengungkapan mengenai kehalalan produk hanya PT Mustika Ratu Tbk (MRAT), PT Mayora Indah Tbk (MYOR) dan PT. Kimia Farma (Persero) Tbk (KAEF). Pada tahun 2011 dan 2012, perusahan juga mengalami peningkatan dalam melakukan pengungkapan kehalalan produknya, yakni terdiri dari PT Kimia Farma (Persero) Tbk (KAEF), PT Mustika Ratu Tbk (MRAT), PT Mayora Indah Tbk (MYOR), PT Sampoerna Agro Tbk (SGRO), PT Semen Gresik (Persero) Tbk (SMGR), dan PT Surya Semesta Internusa Tbk (SSIA) Tbk. Hal ini memberikan dampak positif bagi para pemangku kepentingan Muslim, khususnya konsumen Muslim, untuk mengetahui apakah produk yang dihasilkan perusahaan tersebut halal atau tidak. Meskipun menurut BAPEPAM dan LK perusahaan yang masuk dalam Daftar Efek Syariah merupakan perusahaan yang produknya tidak bertentangan dengan prinsip syariah, sebagian besar perusahaan masih tidak mengungkapkan mengenai kehalalan produknya dalam laporan perusahaan. Dengan demikian, perusahaan yang tidak mengungkapkan kehalalan produk dalam laporannya bukan berarti bahwa produk yang dihasilkan perusahaan tersebut tidak halal. Oleh karena itu, alahkah lebih baik apabila perusahaan-perusahaan yang dikategorikan sebagai perusahaan syariah tersebut melakukan pengungkapan mengenai status kehalalan produk dalam laporannya.

Pokok pengungkapan yang ketiga dan keempat adalah keamanan dan kualitas produk serta pelayanan pelanggan. Pokok pengungkapan ini menekankan pada pengungkapan sistem manajemen mutu, pelayanan jual-beli, dan penanganan komplain atau keluhan konsumen. Kedua pokok pengungkapan ini merupakan pokok pengungkapan yang paling banyak dilakukan oleh perusahaan. Hal ini menunjukkan bahwa keamanan dan kualitas produk serta pelayanan pelanggan telah menjadi concern utama 
bagi sebagian besar perusahaan dalam rangka memenuhi kebutuhan dan keinginan konsumen Muslim.

Secara keseluruhan, perusahaanperusahaan yang melakukan pengungkapan terhadap tema produk dan jasa mengalami peningkatan. Dengan demikian, dapat disimpulkan bahwa semakin ke sini perusahaan syariah semakin berupaya memenuhi informasiinformasi yang dibutuhkan oleh konsumen Muslim.

\section{Karyawan}

Tema karyawan terdiri dari tiga belas pokok pengungkapan. Pada tahun 2010, 2011, dan 2012, pokok pengungkapan tunjangan dan remunerasi merupakan pokok pengungkapan yang paling penting banyak dilakukan oleh perusahaan. Hal ini menunjukkan bahwa tunjangan dan remunerasi merupakan aspek paling penting bagi kesejahteraan karyawan sehingga perusahaan sudah seharusnya memberikan tunjangan dan remunerasi yang memadai kepada seluruh karyawannya.

Selain tunjangan dan remunerasi, pokok pengungkapan mengenai pendidikan dan pelatihan kerja atau pengembangan sumber daya manusia juga menjadi sorotan penting bagi perusahaan. Hasil content analysis menunjukkan bahwa terdapat 60 perusahaan di tahun 2010-2012 yang melakukan pengungkapan terkait pendidikan dan pelatihan kerja atau pengembangan sumber daya manusia dalam laporannya. Hal ini menunjukkan bahwa sebagian besar perusahaan berkomitmen untuk selalu meningkatkan kualitas dan kompetensi karyawankaryawannya. Perusahaan biasanya memberikan pendidikan dan pelatihan dengan memperhatikan kebutuhan karyawan secara personal. Pendidikan dan pelatihan yang diberikan bertujuan untuk meningkatkan pengetahuan, keterampilan, motivasi, sikap, produktifitas, dan karir. Di beberapa perusahaan biasanya juga terdapat kegiatan survei yang dilakukan untuk menilai efektivitas dan efisiensi agar pendidikan dan pelatihan tidak hanya berorientasi pada kualitas tetapi juga berorientasi pada kuantitas. Pokok pengungkapan ini tampak pada bentuk dan sistem pendidikan dan pelatihan, frekuensi pendidikan dan pelatihan, jumlah karyawan yang mengikuti pendidikan dan pelatihan, dan biaya yang dikeluarkan untuk pendidikan dan pelatihan tersebut.

Selanjutnya, sekitar $80 \%$ perusahaan melakukan pengungkapan mengenai kesehatan dan keselamatan kerja, lingkungan kerja dan kesetaraan hak antara pria dan wanita. Pokok pengungkapan mengenai kesehatan dan keselamatan kerja serta lingkungan kerja terlihat dari pelaksanaan dan evaluasi pengelolaan Lingkungan, Kesehatan, dan Keselamatan Kerja (LK3) perusahaan, contohnya zero accident program dan sertifikasi dari pihak independen seperti OHSAS 18001 Sistem Manajemen Keselamatan dan Kesehatan Kerja. Sedangkan, pokok pengungkapan mengenai kesetaraan hak antara pria dan wanita terlihat dari komitmen perusahaan untuk menjungjung tinggi asas kewajaran dan kesetaraan dengan cara memberikan kesempatan yang sama kepada seluruh karyawan tanpa membedakan suku, agama, ras, golongan, gender, dan kondisi fisik yang merujuk pada Hak Asasi Manusia (HAM), Undang-undang Ketenagakerjaan, dan berbagai konvensi International Labour Organization (ILO).

Selanjutnya, terlihat bahwa
perusahaan tidak terlalu menaruh
perhatian penuh pada pengungkapan jam
kerja, hari libur dan cuti, keterlibatan
karyawan dalam diskusi manajemen dan
pengambilan keputusan, karyawan dari
kelompok khusus, karyawan tingkat atas
melaksanakan ibadah bersama-sama
dengan karyawan tingkat menengah dan
tingkat bawah, karyawan Muslim
diperbolehkan menjalankan ibadah di
waktu-waktu shalat dan berpuasa di saat
Ramadhan, dan tempat ibadah yang
memadai. Hanya sekitar 0\%-53\%
perusahaan yang melakukan
pengungkapan terhadap masing-masing
pokok pengungkapan tersebut. Hal ini
mengindikasikan bahwa terdapat hak-hak


dasar karyawan Muslim yang belum diungkapkan secara baik dalam laporan perusahaan.

Dengan demikian, dapat disimpulkan bahwa sebagian besar perusahaan syariah di Indonesia belum melakukan pengungkapan aspek-aspek karyawan secara komprehensif. Padahal, perusahaan sudah seharusnya memenuhi kebutuhan spiritual karyawan dan mengungkapkannya dalam laporan perusahaan agar masyarakat Islam mengetahui apakah karyawan-karyawan perusahaan telah diperlakukan sesuai dengan ajaran Islam (Haniffa, 2002 dan Othman dan Thani).

\section{Masyarakat}

Pokok pengungkapan pada tema masyarakat terbagi menjadi sebelas bagian. Selaras dengan tema-tema lain, secara rata-rata, jumlah perusahaan yang melakukan pengungkapan terhadap pokok-pokok pengungkapan masyarakat mengalami peningkatan. Pokok pengungkapan yang paling banyak diungkapkan di tahun 2010-2012 adalah pengungkapan sedekah, donasi, atau sumbangan. Hal ini mengindikasikan bahwa sebagian besar perusahaan syariah di Indonesia telah memiliki kesadaran yang baik mengenai pentingnya melakukan infak dan sedekah dengan tujuan untuk saling meringankan beban orang lain. Meskipun demikian, bentuk saling berbagi yang lain, seperti wakaf dan qard hassan, masih kurang lazim dilakukan oleh berbagai perusahaan. Informasi tersebut diperoleh dari hasil content analysis yang menunjukkan bahwa pada tahun 20102012 tidak ada perusahaan yang mengungkapkan bahwa mereka telah memberikan wakaf dan qard hassan kepada pihak lain..

Pokok pengungkapan lain yang cukup menonjol dalam laporan-laporan perusahaan adalah pengungkapan mengenai peningkatan kualitas hidup masyarakat miskin, kepedulian terhadap anak-anak, kegiatan amal atau kegiatan sosial, dan menyokong kegiatan-kegiatan kesehatan, hiburan, olahraga, budaya, pendidikan, dan keagamaan. Perihal tersbut cukup menjadi sorotan utama setiap perusahaan karena kesejahteraan masyarakat, khususnya masyarakat sekitar, merupakan indikator yang sangat erat hubungannya dengan konsep tanggung jawab sosial. Perusahaan memiliki tanggung jawab untuk meningkatkan kesejahteraan masyarakat sebagai salah satu upaya dalam rangka meningkatkan pertumbuhan ekonomi negara. Salah satu bentuk dukungan pemerintah terhadap peningkatan kualitas masyarakat miskin diwujudkan melalui Program Kemitraan dan Bina Lingkungan (PKBL) yang diwajibkan bagi seluruh BUMN yang tertuang dalam Peraturan Menteri Negara BUMN Nomor PER05/MBU/2007 tentang Program Kemitraan BUMN dengan Usaha Kecil dan Program Bina Lingkungan.

Pokok pengungkapan lain yang tidak terlalu banyak dilakukan perusahaan terkait dengan sukarelawan dari kalangan karyawan, pemberian beasiswa sekolah, pemberdayaan kerja para lulusan sekolah/kuliah, dan pembangunan tunas muda. Berdasarkan hasil content analysis, keempat program tersebut merupakan program yang tidak umum dimiliki seluruh perusahaan. Karakteristik keempat program tersebut sifatnya bergantung pada kebijakan masing-masing perusahaan dengan memperhitungkan terlebih dahulu tujuan, biaya, dan manfaat dari keempat program tersebut bagi perusahaan.

Dengan demikian, dapat
disimpulkan bahwa kepedulian
perusahaan syariah di Indonesia terhadap masyarakat sudah tergolong baik. Penjelasan terkait biaya yang dikeluarkan, pihak yang menerima bantuan, dan bukti konkrit berupa foto juga telah diungkapkan secara komprehensif oleh sebagian besar perushaan. Meskipun demikian, masih terdapat keterbatasan dalam pengungkapan aspek-aspek spesifik yang terkait dengan prinsip Islam, seperti wakaf dan qard hassan. Perusahaan syariah seharusnya melakukan pengungkapan secara detail dan lengkap tidak terkecuali terhadap aspek-aspek spesifik yang terkait 
dengan prinsip Islam agar para pemangku kepentingan Muslim mengetahui apakah tanggung jawab sosial yang diberikan perusahaan kepada masyarakat telah sesuai dengan prinsip Islam.

\section{Lingkungan}

Tema lingkungan terbagi menjadi lima pokok pengungkapan. Dalam kurun waktu 2010 sampai 2012, jumlah perusahaan yang melakukan pengungkapan terhadap masing-masing pokok pengungkapan pada tema lingkungan mengalami peningkatan. Pokok pengungkapan yang paling banyak dilakukan oleh perusahaan adalah pokok pengungkapan konservasi lingkungan, yakni sebanyak 35 perusahaan di tahun 2010, lalu 36 perusahaan di tahun 2011, dan 51 perusahaan di tahun 2012. Pokok pengungkapan tertinggi kedua dan ketiga adalah pokok pengungkapan kegiatan mengurangi efek terhadap pemanasan global dan sistem manajemen lingkungan. Kegiatan mengurangi efek terhadap pemanasan global dapat diwujudkan dalam bentuk minimalisasi polusi, pengelolaan limbah, pengelolaan air bersih, dan lain-lain. Salah satu tanda yang menunjukkan bahwa perusahaan memiliki sistem manajemen lingkungan yang baik terlihat dari kepemilikan sertifikasi ISO 14001 Sistem Manajemen Lingkungan. Ketiga pokok pengungkapan tersebut sebagian besar dilakukan oleh perusahaan di industri pertambangan, properti, dan perkebunan.

Selain itu, pokok pengungkapan selanjutnya yang hanya menjadi concern utama tidak lebih dari $30 \%$ perusahaan adalah pokok pengungkapan pendidikan mengenai lingkungan dan pernyataan verifikasi independen atau audit lingkungan. Salah satu faktor yang menyebabkan tidak banyaknya perusahaan yang melakukan dan mengungkapkan mengenai pernyataan verifikasi independen atau audit lingkungan adalah faktor biaya. Oleh karena itu, biasanya perusahaan yang telah melakukan dan mengungkapkan hal tersebut hanyalah perusahan-perusahaan besar.
Secara $\begin{gathered}\text { keseluruhan, dapat } \\ \text { disimpulkan bahwa kesadaran dan } \\ \text { kepatuhan perusahaan terhadap }\end{gathered}$
ben lingkungan semakin meningkat seiring dengan semakin rusaknya alam semesta akibat aktivitas operasi berbagai perusahaan. Tanggung jawab perusahaan terhadap lingkungan diwujudkan oleh perusahaan dalam komitmen untuk selalu menjaga, memelihara, dan melestarikan lingkungan. Meskipun demikian, peningkatan kesadaran dan kepedulian terhadap lingkungan hanya konsisten terjadi pada perusahaan besar. Dengan kata lain, masih banyak perusahaan kecil yang kurang peduli terhadap lingkungan. Hal tersebut seharusnya tidak terjadi pada perusahaan yang tergolong sebagai perusahaan syariah. Perusahaan syariah seharusnya memiliki rasa kesadaran dan kepedulian terhadap lingkungan yang lebih baik dibandingkan dengan perusahaan non-syariah karena sesungguhnya Allah SWT tidak menyukai segala bentuk kerusakan yang ada di bumi.

6. Tata Kelola Perusahaan

Tema tata kelola perusahaan mencakup sembilan pokok pengungkapan. Di anatara kelima tema sebelumnya, tema tata kelola perusahaan merupakan tema yang paling konsisten diungkapkan oleh perusahaan syariah di Indonesia. Pokok pengungkapan yang hampir dilakukan oleh seluruh perusahaan adalah pokok pengungkapan struktur kepemilikian saham dan profil Dewan Direksi dan profil Dewan Komisaris. Ketiga pokok pengungkapan tersebut merupakan pokok pengungkapan yang diwajibkan oleh BAPEPAM dan LK yang dituangkan dalam Peraturan BAPEPAM-LK Nomor K.X.6. meskipun telah diwajibkan, ada beberapa perusahaan yang tidak mengungkapkan mengenai struktur saham dan/atau profil Dewan Direksi dalam laporan tahunan meraka, yakni PT Kokoh Inti Arebama Tbk (KOIN).

Di sisi lain, pokok pengungkapan yang tidak dilakukan sama sekali oleh perusahaan adalah pokok pengungkapan mengenai status kepatuhan terhadap 
syariah, pengungkapan ada atau tidaknya praktik menimbun bahan kebutuhan pokok, dan pengungkapan ada atau tidaknya praktik manipulasi harga. Status kepatuhan syariah secara implist tercakup dalam Keputusan Ketua BAPEPAM dan LK tentang Daftar efek Syariah yang diterbitkan setiap periode. Namun, meskipun ketua BAPEPAM dan LK telah menyatakan bahwa perusahaan tersebut merupakan perusahaan yang kegiatan usahanya tidak melakukan pengungkapan terkait dengan status kepatuhan terhadap syariah dalam laporannya. Pokok pengungkapan terkait dengan ada atau tidaknya praktik menimbun bahan kebutuhan pokok dan praktik manipulsi harga tidak dilakukan oleh perusahaan diduga karena pengungkapan tersebut bisa dikatakan sebagai pengungkapan yang dapat merusak citra perusahaan.

$\begin{array}{ccc}\text { Dari } & \text { kedelapan } & \text { pokok } \\ \text { pengungkapan, } & \text { hanya } & \text { pokok }\end{array}$ pengungkapan ada atau tidaknya perkara hukum yang mengalami penurunan. Pada tahun 2010 terrdapat 28 perusahaan, lalu di tahun 2011 terdapat penurunan yakni 27 perusahaan dan terakhir pada tahun 2012 terdapat 29 perusahaan yang melakukan pengungkapan mengenai ada atau tidaknya perkara hukum. Penurunan ini dapat mengandung arti, yakni perkara hukum yang dihadapi perusahaan semakin berkurang tetapi tidak diungkapkan dalam laporan perusahaan atau perusahaan semakin enggan untuk mengungkapkan ada atau tidaknya perkara hukum yang sedang dialami oleh perusahaan. Perusahaan menganggap tidak melakukan pengungkapan terhadap ada atau tidaknya perkara hukum mengindikasi bahwa perusahaan tidak terlibat dalam perkara hukum sama sekali. Seperti yang kita ketahui bersama, ketidakterlibatan perusahaan dalam perkara hukum merupakan salah satu upaya untuk menjaga dan meningkatkan citra perusahaan di mata publik. Selain itu, Peraturan BAPEPAM-LK Nomor X.K.6 hanya mewajibkan pengungkapan terkait dengan perkara hukum yang sedang dihadapi oleh perusahaan, anggota Dewan Direksi, dan anggota Dewan
Komisaris yang sedang menjabat. Dengan kata lain, apabila perusahaan tidak sedang terlibat dalam perkara hukum, BAPEPAMLK tidak mewajibkan perusahaan untuk mencantumkannya dalam laporan tahunan perusahaan.

Secara keseluruhan, dapat disimpulkan bahwa pengungkapan perusahaan syariah terhadap tema tata kelola perusahaan masih didominasi dengan motivasi hanya untuk mematuhi pengungkapan wajib dari BAPEPAM dan LK. Padahal, sebagai perusahaan syariah, sudah seharusnya perusahaan melakukan pengungkapan tata kelola perusahaan berbasis syariah dengan seluas-luasnya. Informasi tersebut sangat bermanfaat bagi para investor Muslim dalam proses pengambilan keputusan. Berdasarkan hasil survei yang dilakukan oleh McKinsey pada tahun 2002, investor akan bersedia membeli saham dengan harga premium untuk perusahaan yang memiliki tata kelola perusahaan berkualitas tinggi.

\section{Uji Asumsi Klasik}

Uji asumsi klasik dilakukan untuk mengetahui kelayakan penggunaan model penelitian ini.Pengujian ini bertujuan untuk memastikan bahwa di dalam regresi terdapat normalitas dan tidak terdapat, multikolinearitas, hetorkedastisitas, autokorelasi, serta untuk memastikan bahwa data yang dihasilkan berdistribusi normal (Ghozali, 2013).

\section{Uji Normalitas}

Uji normalitas bertujuan untuk menguji apakah dalam model regresi, variabel penggangu atau residual memiliki distribusi normal (Ghozali, 2013).

\section{Gambar 2 Hasil Uji Normalitas}

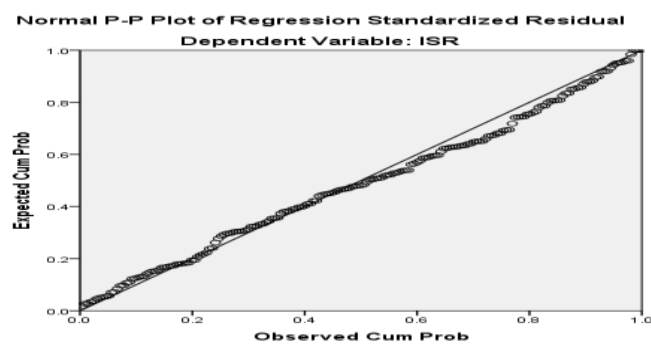

Sumber : Output SPSS, 2015 
Berdasarkan gambar 1 diatas dapat disimpulkan bahwa pada garfik normal plot terlihat titik - titik yang menyebar disekitar garis diagonal, maka hal ini menunjukan bahwa model regresi tersebut berdistribusi normal artinya model regresi layak dipakai karena memenuhi asumsi normalitas.

\section{Uji Multikolinearitas}

Uji multikolinearitas bertujuan untuk menguji apakah dalam model regresi menemukan adanya korelasi antara variabel independen, maka uji jenis ini hanya diperuntukan penelitian yang memiliki variabel independen lebih dari satu.

Tabel 5. Hasil Uji Multikolinearitas Coefficients $^{\mathrm{a}}$

\begin{tabular}{|c|c|c|c|c|c|c|c|c|}
\hline \multirow{2}{*}{\multicolumn{2}{|c|}{ Model }} & \multicolumn{2}{|c|}{$\begin{array}{l}\text { Unstandardized } \\
\text { Coefficients }\end{array}$} & \multirow{2}{*}{$\begin{array}{c}\begin{array}{c}\text { Standardized } \\
\text { Coefficients }\end{array} \\
\text { Beta }\end{array}$} & \multirow[t]{2}{*}{$\mathrm{t}$} & \multirow[t]{2}{*}{ Sig. } & \multicolumn{2}{|c|}{ Collinearity Statistics } \\
\hline & & $B$ & $\begin{array}{l}\text { Std. } \\
\text { Error }\end{array}$ & & & & Tolerance & VIF \\
\hline & (Constant) & -103.433 & 13.500 & & -7.662 & .000 & & \\
\hline & SIZE & 5.265 & .481 & .624 & 10.948 & .000 & .977 & 1.024 \\
\hline 1 & DINDS & 3.738 & 1.801 & .118 & 2.075 & .039 & .981 & 1.020 \\
\hline & AGE & .309 & .128 & .137 & 2.406 & .017 & .978 & 1.023 \\
\hline & SUKUK & -23.547 & 7.159 & -.187 & -3.289 & .001 & .978 & 1.022 \\
\hline
\end{tabular}

a. Dependent Variable: ISR

Sumber : Output SPSS, 2015.

Tabel 5 menunjukan bahwa masing - masing variabel independen memiliki nilai tolerance lebih dari 0.10 yang berarti tidak terdapat korelasi antara variabel independen. Sedangkan untuk nilai VIF menunjukan Masing - masing variabel independen tidak memiliki nilai VIF lebih dari 10. Sehingga dapat disimpulkan bahwa ke empat variabel independen tidak memiliki masalah multikolinearitas.

\section{Uji Heteroskedastisitas}

Uji heteroskedastisitas bertujuan untuk menguji apakah dalam model regresi terjadi ketidak samaan varians dari residual suatu pengamatan ke pengamatan yang lainnya (Ghozali, 2013).
Gambar 3 Hasil Uji Heterokedastisitas

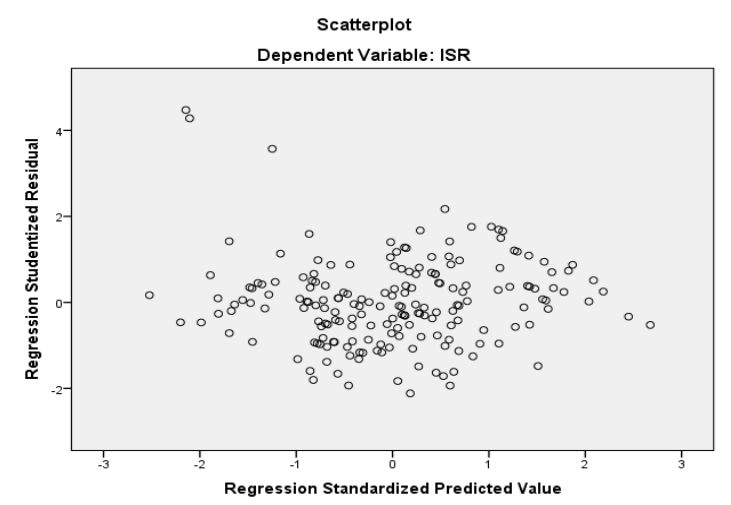

Sumber : Output SPSS, 2015.

Berdasarkan gambar 3 diatas menunjukan bahwa dalam diagram scatterplot dapat dilihat bahwa titik - titik menyebar secara acak baik diatas maupun dibawah 0 pada sumbu $\mathrm{Y}$, dengan 
demikian dapat disimpulkan bahwa tidak terjadi heteroskedastisitas pada model regresi.

\section{Uji Autokorelasi}

Uji autokorelasi dilakukan untuk menguji apakah dalam model regresi linier terdapat korelasi antara kesalahan penggangu pada priode $t$ dengan kesalahan penggangu pada $\mathrm{t}-1$ (sebelumnya).

Tabel 6. Hasil Uji Autokorelasi

\begin{tabular}{|l|c|c|r|r|r|}
\hline \multicolumn{7}{|c|}{ Model Summary } \\
\hline $\begin{array}{l}\text { Mode } \\
\text { I }\end{array}$ & $\mathrm{R}$ & $\begin{array}{c}\mathrm{R} \\
\text { Squar } \\
\mathrm{e}\end{array}$ & $\begin{array}{c}\text { Adjuste } \\
\mathrm{d} \mathrm{R} \\
\text { Square }\end{array}$ & $\begin{array}{c}\text { Std. } \\
\text { Error of } \\
\text { the } \\
\text { Estimate }\end{array}$ & $\begin{array}{c}\text { Durbin- } \\
\text { Watso } \\
\mathrm{n}\end{array}$ \\
\hline 1 & $\begin{array}{r}646 \\
\mathrm{a}\end{array}$ & .417 & .404 & $\begin{array}{r}12.1676 \\
4\end{array}$ & 2.186 \\
\hline
\end{tabular}

a. Predictors: (Constant), SUKUK, AGE, DINDS, SIZE

b. Dependent Variable: ISR

Sumber : Output SPSS, 2015.

Dapat dilihat pada tabel 6 diatas, hasil SPSS menunjukan bahwa nilai D-W sebesar 2.186 dengan demikian berada diantara du =1,54 dan 4-du =2,46 maka artinya tidak terdapat autokorelasi.

\section{Analisis Regresi Linier Berganda}

Metode regresi berganda ini dikembangkan untuk menguji nilai variabel dependent dengan menggunakan lebih dari satu variabel independent (Damayanti, 2011). Hasil pengujian model regresi berganda diperoleh sebagai berikut :
Tabel 7 Hasil Regresi Linier Berganda Coefficients ${ }^{a}$

\begin{tabular}{|c|c|c|c|c|c|}
\hline \multirow[t]{2}{*}{ Model } & \multicolumn{2}{|c|}{$\begin{array}{l}\text { Unstandardi } \\
\text { zed } \\
\text { Coefficients }\end{array}$} & \multirow{2}{*}{$\begin{array}{c}\text { Standardi } \\
\text { zed } \\
\text { Coefficien } \\
\text { ts }\end{array}$} & \multirow[t]{2}{*}{$\mathrm{t}$} & \multirow[t]{2}{*}{$\begin{array}{l}\text { Si } \\
\text { g. }\end{array}$} \\
\hline & $B$ & $\begin{array}{l}\text { Std. } \\
\text { Error }\end{array}$ & & & \\
\hline $\begin{array}{l}\text { (Consta } \\
\text { nt) }\end{array}$ & $\begin{array}{r}- \\
103.4 \\
33\end{array}$ & $\begin{array}{r}13.5 \\
00\end{array}$ & & $\begin{array}{r}- \\
7.66 \\
2\end{array}$ & $\begin{array}{r}.00 \\
0\end{array}$ \\
\hline SIZE & 5.265 & .481 & .624 & $\begin{array}{r}10.9 \\
48\end{array}$ & $\begin{array}{r}.00 \\
0\end{array}$ \\
\hline 1 DINDS & 3.738 & $\begin{array}{r}1.80 \\
1\end{array}$ & .118 & $\begin{array}{r}2.07 \\
5\end{array}$ & $\begin{array}{r}.03 \\
9\end{array}$ \\
\hline AGE & .309 & .128 & .137 & $\begin{array}{r}2.40 \\
6\end{array}$ & $\begin{array}{r}.01 \\
7\end{array}$ \\
\hline SUKUK & $\begin{array}{r}- \\
23.54 \\
7\end{array}$ & $\begin{array}{r}7.15 \\
9\end{array}$ & -.187 & $\begin{array}{r}- \\
3.28 \\
9\end{array}$ & $\begin{array}{r}.00 \\
1\end{array}$ \\
\hline
\end{tabular}

a. Dependent Variable: ISR

Sumber: Output SPSS, 2015.

Dapat dilihat pada tabel 7 menunjukan angka - angka pada variabel ukuran perusahaan, jenis industri, umur perusahaan, dan penerbitan sukuk. Didapat hasil persamaan regresi yaitu :

$$
Y=-103.433+5.265 X_{1}+3.738 X_{2}+0.309
$$
$X_{3}-23.547 X_{4}$

Adapun interprestasi dari persamaan tersebut adalah :

1. Nilai konstan ini menunjukan bahwa apabila tidak ada variabel ukuran perusahaan, jenis industri, umur perusahaan, dan penerbitan sukuk maka tingkat pengungkapan Islamic social reportingakan sebesar 103.433.

2. Nilai parameter atau koefisien regresi $X_{1}$ ini menunjukan bahwa setiap variabel ukuran perusahaann meningkat 1, maka tingkat pengungkapan Islamic social reporting akan meningkat sebesar 5.265 dengan asumsi variabel lain tetap.

3. Nilai parameter atau koefisien regresi $X_{2}$ ini menunjukan bahwa setiap variabel jenis industri meningkat 1, maka tingkat pengungkapan Islamic social reporting akan meningkat sebesar 
3.738 dengan asumsi variabel lain tetap.

4. Nilai parameter atau koefisien regresi $X_{3}$ ini menunjukan bahwa setiap variabel umur perusahaan meningkat 1, maka tingkat pengungkapan Islamic social reporting akan naik sebesar 0,309 dengan asumsi variabel lain tetap.

Nilai parameter atau koefisien regresi $\mathrm{X}_{4}$ sebesar-23.547 dan bertanda negatif ini menunjukan bahwa variabel penerbitan sukuk mempunyai hubungan yang berlawanan arah dengan tingkat pengungkapan Islamic social reporting.
Hal ini mengandung arti bahwa setiap penerbitan sukuk meningkat 1, maka tingkat pengungkapan Islamic social reporting akan turun sebesar -23.547 dengan asumsi variabel lain tetap.

\section{Analisis Pengujian Hipotesis}

\section{Uji Signifikan Parsial (Uji-t)}

Uji statistik $t$ pada dasarnya menunjukan seberapa jauh pengaruh satu variabel penjelas/independent sacara individual dalam menerangkan variasi variabel dependent (Ghozali, 2013). Hasil statistik t untuk penelitian ini dapat dilihat sebagai berikut :

Tabel 8 Hasil Uji - t

Coefficients $^{a}$

\begin{tabular}{|c|c|c|c|c|c|c|}
\hline \multirow[t]{2}{*}{ Mod } & & \multicolumn{2}{|c|}{$\begin{array}{c}\text { Unstandardized } \\
\text { Coefficients }\end{array}$} & $\begin{array}{c}\text { Standardized } \\
\text { Coefficients }\end{array}$ & \multirow[t]{2}{*}{$\mathrm{T}$} & \multirow[t]{2}{*}{ Sig. } \\
\hline & & $\mathrm{B}$ & Std. Error & Beta & & \\
\hline \multirow{5}{*}{1} & (Constant) & -103.433 & 13.500 & & -7.662 & .000 \\
\hline & SIZE & 5.265 & .481 & .624 & 10.948 & .000 \\
\hline & DINDS & 3.738 & 1.801 & .118 & 2.075 & .039 \\
\hline & AGE & .309 & .128 & .137 & 2.406 & .017 \\
\hline & SUKUK & -23.547 & 7.159 & -.187 & -3.289 & .001 \\
\hline
\end{tabular}

a. Dependent Variable: ISR

Sumber : Output SPSS, 2015.

Berdasarkan tabel 8 dapat ditarik kesimpulan sebagai berikut :

\section{Ukuran Perusahaan}

Dari hasil uji $\mathrm{t}$ diketahui bahwa besarnya nilai $t_{\text {hitung }}$ untuk variabel Ukuran Perusahaan sebesar 10.948 sedangkan $t$ tabel diketahui df (derajat keabsahan) $=\mathrm{n}-$ 2 = yaitu $189-2=187$, sehingga diperoleh $\mathrm{t}$ tabel sebesar 1.65304 dengan tingkat signifikan $a=5 \%$ sebesar 0,000 berdasarkan kriteria dapat diketahui bahwa $\mathrm{t}$ hitung $>\mathrm{t}$ tabel, yaitu $10.948>$ 1.65304 dengan nilai signifikan $=0.000<$ 0.05 maka Ho ditolak dan $\mathrm{Ha}^{1}$ diterima, yang artinya bahwa terdapat pengaruh yang signifikan secara parsial antara variabel ukuran perusahaan terhadap variabel tingkat pengungkapan Islamic Social Reporting

\section{Jenis Industri}

Dari hasil uji $\mathrm{t}$ diketahui bahwa besarnya nilai $t$ hitung untuk variabel jenis industri sebesar 2.075 sedangkan $t$ tabel diketahui df (derajat keabsahan) $=\mathrm{n}-2=$ yaitu $189-2=187$, sehingga diperoleh $t$ tabel sebesar 1.65304 dengan tingkat signifikan $a=5 \%$ sebesar 0,039 berdasarkan kriteria dapat diketahui bahwa $t_{\text {hitung }}>t_{\text {tabel, }}$ yaitu $2.075>1.65304$ dengan nilai signifikan $=0.039<0.05$ maka $\mathrm{Ho}$ ditolak dan $\mathrm{Ha}^{2}$ diterima, yang artinya bahwa terdapat pengaruh yang signifikan secara parsial antara variabel jenis industri terhadap variabel tingkat pengungkapan Islamic Social Reporting

3. Umur Perusahaan 
Dari hasil uji $\mathrm{t}$ diketahui bahwa besarnya nilai $t$ hitung untuk variabel Umur Perusahaan sebesar 2.406 sedangkan $t$ tabel diketahui df (derajat keabsahan) $=\mathrm{n}-$ 2 = yaitu $189-2=187$, sehingga diperoleh $\mathrm{t}$ tabel sebesar 1.65304 dengan tingkat signifikan $a=5 \%$ sebesar 0,017 berdasarkan kriteria dapat diketahui bahwa $t_{\text {hitung }}>t_{\text {tabel, }}$ yaitu $2.406>1.65304$ dengan nilai signifikan $=0.017<0.05$ maka $\mathrm{Ho}$ ditolak dan $\mathrm{Ha}^{3}$ diterima, yang artinya bahwa terdapat pengaruh yang signifikan secara parsial antara variabel umur perusahaan terhadap variabel tingkat pengungkapan Islamic Social Reporting

\section{Penerbitan Sukuk}

Dari hasil uji $\mathrm{t}$ diketahui bahwa besarnya nilai $t$ hitung untuk variabel penerbitan sukuk sebesar -3.289 sedangkan $\mathrm{t}$ tabel diketahui df (derajat keabsahan) $=\mathrm{n}-2=$ yaitu $189-2=187$, sehingga diperoleh $t$ tabel sebesar 1.65304 dengan tingkat signifikan $a=5 \%$ sebesar 0,001 berdasarkan kriteria dapat diketahui bahwa $t_{\text {hitung }}<t_{\text {tabel, }}$ yaitu $-3.289<1.65304$ dengan nilai signifikan $=0.001<0.05$ maka Ho diterima dan $\mathrm{Ha}^{4}$ ditolak, yang artinya bahwa tidak berpengaruh secara parsial antara variabel penerbitan sukuk terhadap variabel tingkat pengungkapan Islamic Social Reporting.

\section{Uji Signifikan Simultan (Uji-F)}

Uji statistik $F$ pada dasarnya menunjukkan apakah semua variabel independen yang dimasukkan dalam model mempunyai pengaruh secara bersama-sama terhadap variabel dependen (Ghozali, 2013: 98). Hasil uji statistik $F$ untuk penelitian ini dapat dilihat pada tabel berikut :

Tabel 9 Hasil Uji - F
\begin{tabular}{|l|r|r|r|r|r|}
\hline ANodel & Sum of & Df & Mean & F & Sig. \\
& Squares & & Square & & \\
\hline Regressi & 19466.0 & 4 & 4866.5 & 32.8 & .00 \\
on & 81 & & 20 & 70 & $0^{\mathrm{b}}$ \\
1 Residual & 27241.4 & 18 & 148.05 & & \\
& 47 & 4 & 1 & & \\
Total & 46707.5 & 18 & & & \\
29 & 8 & & & \\
\hline
\end{tabular}

a. Dependent Variable: ISR

b. Predictors: (Constant), SUKUK, AGE, DINDS, SIZE

Sumber : Output SPSS, 2015.

Dari tabel 9 dapat diketahui $\mathrm{k}=5$ yaitu Ukuran Perusahaan $\left(X^{1}\right)$, Jenis Industri $\left(X^{2}\right)$, Umur Perusahaan $\left(X^{3}\right)$, Penerbitan Sukuk $\left(X^{4}\right), \quad$ dan Pengungkapan Islamic Social Reporting $(Y)$, sedangkan jumlah $n$ adalah 189. Jadi derajat pembilang pada tabel distribusi $F$ adalah $\mathrm{k}-1=4$ sedangkan derajat penyebutnya adalah $n-k=184$. Dari hasil tersebut menunjukan nilai $F_{\text {hitung yang }}$ diperoleh sebesar 32.870 sedangkan nilai $F$ tabel sebesar 2.42 dengan signifikansi 0,000 . Dari hasil tersebut, maka diketahui $\mathrm{F}$ hitung $>\mathrm{F}$ tabel,dengan nilai signifikansi $0,000<0,05$, maka dapat disimpulkan bahwa variabel Ukuran Perusahaan $\left(X^{1}\right)$, Jenis Industri $\left(X^{2}\right)$, Umur Perusahaan $\left(X^{3}\right)$, dan Penerbitan Sukuk $\left(X^{4}\right)$ secara simultan berpengaruh signifikan terhadap Pengungkapan Islamic Social Reporting.

\section{Koefisien Determinasi}

Koefisien determinasi (R2) pada intinya mengukur seberapa jauh kemampuan model dalam menerangkan variasi variabel dependent. Nilai koefisien determinasi adalah antara nol dan satu (0 $<\mathrm{R}<1$ ). Semakin besar koefisien determinasinya maka semakin besar variasi variabel independentnya mempengaruhi variabel dependentnya.

\section{Tabel 10}

Hasil Uji Koefisien Determinasi

\begin{tabular}{|l|l|l|l|l|l|}
\hline \multicolumn{2}{|l|}{ Model Summary } \\
\hline $\begin{array}{l}\text { Mode } \\
\text { I }\end{array}$ & $\mathrm{R}$ & $\begin{array}{l}\text { R } \\
\text { Squar } \\
\mathrm{e}\end{array}$ & $\begin{array}{l}\text { Adjuste } \\
\text { d R } \\
\text { Square }\end{array}$ & $\begin{array}{l}\text { Std. } \\
\begin{array}{l}\text { Error of } \\
\text { the } \\
\text { Estimate }\end{array}\end{array}$ & $\begin{array}{l}\text { Durbin- } \\
\text { Watso } \\
\mathrm{n}\end{array}$ \\
\hline 1 & $\begin{array}{l}.646 \\
\mathrm{a}\end{array}$ & .417 & .404 & $\begin{array}{l}12.1676 \\
4\end{array}$ & 2.186 \\
\hline
\end{tabular}

Sumber : Output SPSS, 2015.

Berdasarkan pada tabel 10 Koefisien determinasi dinotasikan dengan adjusted $\mathrm{R}^{2}$. Nilai adjusted $\mathrm{R}^{2}$ dalam penelitian sebesar $40.3 \%$ mengandung arti bahwa variabel terikat skor indeks Islamic Social Reporting mampu 
dijelaskan $40.3 \%$ oleh variabel bebas dalam model, sedangkan 59.7\% dijelaskan oleh faktor-faktor lain yang tidak termasuk dalam penelitian.

\section{KESIMPULAN}

Dari hasil analisis penelitian yang dilakukan pada bab sebelumnya, kesimpulan yang dapat ditarik adalah sebagai berikut:

Ukuran perusahaan memiliki pengaruh positif signifikan terhadap tingkat pengungkapan Islamic Social Reporting, hal tersebut dilihat dari hasil pengujian hipotesis dengan nilai $t$ hitung $>t$ tabel, yaitu $10.948>1.65304$. Penelitian ini berhasil menunjukan bahwa perusahaan syariah yang lebih besar memiliki kecenderungan untuk melakukan pengungkapan tanggung jawab sosial secara syariah yang lebih luas dibandingkan dengan perusahaan syariah yang lebih kecil.

Jenis industri memiliki pengaruh positif signifikan terhadap tingkat pengungkapan Islamic Social Reporting, hal tersebut dilihat dari hasil pengujian hipotesis dengan nilai $t$ hitung $>t$ tabel, yaitu $2.075>1.65304$. Penelitian ini berhasil menunjukan tingkat pengungkapan tanggung jawab yang sesuai dengan prinsip Islam pada perusahaan syariah manufaktur dan non-manufaktur relatif tidak ada perbedaan yang signifikan.

Umur Perusahaan terbukti memiliki pengaruh positif signifikan terhadap tingkat pengungkapan Islamic Social Reporting, hal tersebut dilihat dari hasil pengujian hipotesis level a $5 \%(0,017>$ $0.05)$ dengan nilai $t$ hitung $>t$ tabel yaitu 2.406 $>$ 1.65304. Penelitian ini berhasil menunjukan perusahaan yang lebih muda akan lebih memiliki kecenderungan untuk melakukan pengungkapan tanggung jawab sosial secara syariah yang lebih luas dibandingkan dengan perusahaan syariah yang lebih tua.

Penerbitan sukuk tidak pengaruh terhadap tingkat pengungkapan Islamic Social Reporting, hal tersebut dilihat dari hasil pengujian hipotesis dengan nilai $t$ hitung $<\mathrm{t}$ tabel, yaitu $-3.289<1.65304$. Salah satu alasan yang menyebabkan masih sangat minimnya perusahaan syariah di Indonesia yang menjadikan sukuk sebagai salah satu sumber pendanaan mereka sehingga kesadaran antara perusahaan yang menerbitkan sukuk relatif tidak ada perbedaan dalam hal melakukan/ pengungkapan tanggung jawan sosial yang sesuai dengan prinsip Islam.

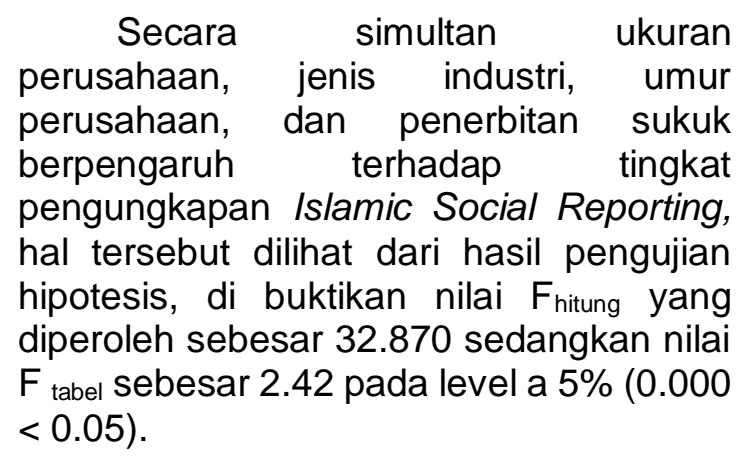

\section{IMPLIKASI KETERBATASAN}

DAN

Penelitian lanjutan suatu hal penting dalam rangka mendukung perkembangan Islamic Social Reporting di Indonesia. Berikut adalah saran penulis untuk penelitian selanjutnya:

Memperluas jumlah sampel dengan memperpanjang periode penelitian menjadi empat tahun atau lebih. Selain itu, penelitian selanjutnya dapat menggunakan daftar perusahaan yang masuk dalam Indexs Saham Syariah Indonesia (ISSI) yang baru di terbitkan oleh BEI. Dengan menggunakan indeks tersebut, penelitian selanjutnya diharapkan lebih manggambarkan kondisi pasar modal syariah Indonesia yang sebenarnya.

Penelitian selanjutnya harus dapat mengembangkan pokok-pokok pengungkapan indeks ISR secara lebih komprehensif dengan tidak lupa memperhatikan karakteristik dan kondisi di Indonesia. Hal ini dilakukan agar indeks ISR yang digunakan dapat lebih merefleksikan tanggung jawab sosial yang sesuai dengan prinsip Islam dan dapat diterapkan di Indonesia.

Menambah sumber informasi yang dijadikan sebagai bahan penilaian 
pengungkapan tanggung jawab sosial syariah, seperti press release, informasi yang diungkapkan di situs web perusahaan, dan sumber informasi lain.

\section{DAFTAR PUSTAKA}

Akhtaruddin, M. (2005). Corporate Mandatory Disclosure Practices in Bangladesh. The International Journal of Accounting

Aljifri, K (2008). Annual Report Disclosure in a Developing Country: The Case of the UAE. Advances in acconting, incorporating Advances in International Accounting.

Baroko, D. G. (2007). Determinants of voluntary Disclosure in Kenyan Companies Annual Reports. African Journal of Business Management.

Fitria S. \& Hartanti D. (2010). Islam dan Tanggung Jawab Sosial: Studi Perbandingan Pengungkapan Berdasarkan Global Reporting Initiative Indeks dan Islamic Social Reporting Indeks. Simposium Nasional Akuntansi XIII Purwokerto, 133.

Friedman, M. 1982. Capitalism and Frerdom. USA : The University of Chicago.

Ghozali, Imam, 2013, Aplikasi Analisis Multivariate demgan Program IBM SPSS 21 Update PLS Regresi, Penerbit Universitas Diponogoro, Semarang.

Gray, S. J., Meek, G., \& Roberts, C. (1995). International Capital Market Preassures and Voluntary Annual Report Disclosure by US and UK Multinationals. Journal of International Financial Management and Accounting.

Haniffa, R. (2002). Social Reporting Disclosure-An Islamic Perspective. Indonesian
Management \& Accounting Research.

Haniffa, R.M., \& Cooke, T. E (2002). Culture, Corporate Governance, and Disclosure in Malaysian Corporations. Abacus

http://www.iaiglobal.or.id/prinsip akuntans i/exposure.php?id=13

Ikatan Akuntan Indonesia. (2009, Juni 19). ED PSAK 1 (Revisi 2009) Penyajian Laporan Keuangan. Dari Ikatan Akuntan Indonesia:

Marwata. (2010). Hubungan Antara Karateristik Perusahaan dan Kualitas Ungkapan Sukarela dalam Laporan Tahunan Perusahaan Publik di Indonesia. Simposium Nasional Akuntansi 4, 155-173

Noegraheni, Y. (2010). Pengaruh Karateristik Perusahaan terhadap Kualitas Pengungkapan Sukarela dalam Laporan Tahunan pada Perusahaan Publik Non Industri Keuangan di Bursa Efek Jakarta. EQUITY, 2, 6170

Othman, R., \& Thani, A. M., \& Ghani, E. K. (2009). Determinants of Islamic Social Reporting Among Top Shariah-Approved Companies in Bursa Malaysia. Reaserch Journal of International Studied.

Othman, R., \& Thani, A. M. (2010). Islamic Social Reporting of Listed Companies In Malaysia. International Business \& Economics Research Journal.

Peraturan BAPEPAM-LK Nomor II.K.1 tentang Kriteria dan Penerbitan Daftar Efek Syariah.

Peraturan BAPEPAM-LK Nomor IX.A.13 tentang Penerbitan Efek Syariah. 
Peraturan BAPEPAM-LK Nomor IX.A.14 tentang Akad-akad yang Digunakan dalam Penerbitan Efek Syariah di Pasar Modal.

Peraturan BAPEPAM-LK Nomor X.K.6 tentang Kewajiban Penyampaian Laporan Tahunan bagi Emiten atau Perusahaan Publik.

Putri, Karina Tria, Yuyeta, E. N. A. (2014), "Faktor-Faktor Yang Mempengaruhi Islamic Social Reporting PerusahaanPerusahaan Yang Terdaftar Pada Indeks Saham Syariah Indonesia (Issi) Tahun 20112012", Journal Of Accounting Dippnegogo

Rhimedia, Iridyanti Tineke, (2013), "Analisis Faktor - Faktor Yang Mempengaruhi Tingkat Pengungkapan Islamic Social Reporting (Isr) PerusahaanPerusahaan Yang Terdapat Pada Daftar Efek Syariah (Des) Tahun 2009-2011". Skripsi, STIESA SUBANG. (tidak dipublikasikan).

Sekaran, U., \& Bougie, R.(2010). Research methods for business Fifth Edition. Uk:John Wiley \& Sons.

Undang-Undang Republik Indonesia No. 25 Tahun 2007 tentang Penanaman Modal

Undang-Undang Republik Indonesia No. 40 Tahun 2007 tentang Pasar Terbatas

Undang-Undang Republik Indonesia No. 8 Tahun 1995 tentang Penanaman Modal

Utama, S. (2007). Evaluasi Infrastuktur Pendukung Pelaporan Tanggung Jawab Sosial dan Lingkungan Di Indonesia.

Widiawati, (2012). Analisis faktor-faktor yang Mempengaruhi Islamic Social Reporting PerusahaanPerusahaan yang Terdapat
Pada Daftar Efek Syariah tahun 2009-2011. Jurnal Fakultas Ekonomi Universitas Diponogoro 
(2019) 